\author{
Katarzyna Tomaszewska \\ Uniwersytet Wrocławski \\ e-mail: katarzyna.tomaszewska@uwr.edu.pl \\ ORCID 0000-0003-4024-0036
}

\title{
SYSTEM ORGANÓW KONTROLI \\ NAD RYNKIEM ZAMÓWIEŃ PUBLICZNYCH - \\ POTRZEBA ZMIANY (UWAGI DE LEGE LATA \\ I DE LEGE FERENDA)*
}

\section{SYSTEM OF SUPERVISORY AUTHORITIES \\ OF PUBLIC PROCUREMENT MARKET - \\ NEED FOR A CHANGE (DE LEGE LATA \\ AND DE LEGE FERENDA COMMENTS)}

\author{
DOI: $10.15611 / \mathrm{pn} .2018 .540 .20$ \\ JEL Classification: K10, K11
}

\begin{abstract}
Streszczenie: Kontrolowanie jest niezbędnym elementem prawidłowego funkcjonowania państwa demokratycznego. Obejmuje swym zakresem działania rozmaitych podmiotów, ale jest również przeprowadzane przez zróżnicowane instytucje określane zbiorczo jako system organów kontroli. Pośród niniejszych podmiotów istotne znaczenie mają te, które czuwają nad prawidłowym dysponowaniem środkami publicznymi w obrębie udzielania zamówień publicznych. Określeniu kompetencji niniejszych podmiotów, a szczególnie uwidocznieniu pewnego rodzaju dysfunkcji w ich działalności oraz w obrębie prowadzonych postępowań kontrolnych poświęcone jest niniejsze opracowanie. Umożliwi ono sformułowanie stosownych wniosków obrazujących potrzebę zmian, potrzebę wzmocnienia systemu weryfikowania zamówień publicznych przy pomocy samodzielnego i niezależnego organu nadzoru w zakresie czynności związanych z udzielaniem zamówienia na realizację usługi, dostawy czy też roboty budowlanej.
\end{abstract}

Słowa kluczowe: zamówienia publiczne, kontrola, nadzór, kontrolowanie.

Summary: Control is an indispensable element for a correct functioning of a democratic state. Within its scope it covers operations of different entities but it is also carried out by various institutions collectively defined as the systems of control authorities. Among them of crucial importance are those authorities which ensure that public funds are properly disposed

* Artykuł powstał w ramach projektu badawczego SONATA BIS finansowanego ze środków Narodowego Centrum Nauki, na podstawie decyzji nr DEC-2014/14/E/HS5/00845 (umowa nr UMO$-2014 / 14 / \mathrm{E} / \mathrm{HS} 5 / 00845)$. 
of within the procedure of awarding public procurements. This thesis is devoted to the issue of defining competences of these entities, especially showing a certain kind of drawbacks in their operations and within conducted control procedures. It will allow to formulate appropriate conclusions revealing the need for changes, need for strengthening the system of verification of public procurements with the aid of an independent and autonomous inspection authority in the scope of actions connected with granting procurements for carrying out services, supply or construction works.

Keywords: public procurement, control, supervision, controlling.

\section{Wstęp}

Popularne jest twierdzenie, że proces kontrolowania dotyczy każdego zorganizowanego ludzkiego postępowania ${ }^{1}$. Nierzadko stanowi ono wprowadzenie dla rozważań odnoszących się do problematyki kontrolowania, procesu kontroli i nadzoru. Jak wskazuje S. Jędrzejewski: „Kontrola i nadzór należą do terminów najczęściej używanych $\mathrm{w}$ aktach prawnych dotyczących ustroju i działania organów administracji państwowej..."2. Co istotne, to właśnie z samego jego występowania, częstotliwości użycia oraz z zawartości merytorycznej można wyprowadzić wniosek o szczególnym znaczeniu procesu kontrolowania w demokratycznym państwie prawa. Jak wskazuje ustrojodawca: „Rzeczpospolita Polska jest demokratycznym państwem prawnym, urzeczywistniającym zasady sprawiedliwości społecznej” (art. 2 Konstytucji RP). „Organy władzy publicznej działają na podstawie i w granicach prawa”. Za jedną z gwarancji ustroju demokratycznego i praworządności funkcjonowania organów państwa należy uznać prawidłowo prowadzoną działalność kontrolną, działalność zróżnicowaną, realizowaną przez różnego rodzaju podmioty (nie wykluczając przy tym kontrolowania obywatelskiego). Słuszności niniejszego stanowiska nie przekreśla również monteskiuszowski podział władzy na: władzę ustawodawczą, wykonawczą i sądowniczą. Nieprzypadkowo bowiem mówi się istnieniu tzw. czwartej władzy - władzy kontrolującej, a sam fakt jej wyodrębnienia świadczy o doniosłości procesu polegającego na analizowaniu stanu istniejącego, jego rejestrowaniu i porównywaniu z wzorcami zachowania i ustroju poprawnego ${ }^{3}$.

Będąc istotnym elementem funkcjonowania państwa, prowadzącym do ustalenia istniejącej rzeczywistości i usunięciu z jej ram odkrytych nieprawidłowości, kontrolowanie obejmuje swymi ramami zróżnicowane obszary działalności publicznej związanej z realizacją zadań na rzecz ogółu ludności oraz z dysponowaniem środ-

${ }^{1}$ Zob. m.in. J. Jagielski, Kontrola administracji publicznej, Warszawa 2005, s. 7.

${ }^{2}$ Zob. S. Jędrzejewski, $W$ kwestii ustawowej definicji pojęcia „nadzór”, Organizacja-Metody-Technika, 1989, nr 8-9, s. 2.

${ }^{3}$ Zob. poglądy A. Sylwestrzaka w przedmiocie występowania władzy czwartej zwanej kontrolującą: A. Sylwestrzak, Kontrola administracji publicznej w III Rzeczpospolitej Polskiej, Gdańsk 2006, s. 20 i nast. 
kami publicznymi. Ogół podmiotów, procedur, czynności czy też zachowań związanych z realizacją czynności badawczo-ocennych nad podmiotami publicznymi określany jest mianem systemu kontroli administracji publicznej. Całość zaś organów kontrolujących, funkcjonujących w danym państwie, organów, u podstaw których aktywności legło zapewnienie prawidłowości zachowań podmiotów publicznych w poszczególnych dziedzinach życia publicznego, tworzy system organów kontroli publicznej ${ }^{4}$. Prawidłowe kontrolowanie nie może i nie ogranicza się do występowania tylko jednej instytucji badawczej, ale opiera się na wielości i zróżnicowaniu podmiotowo-przedmiotowym ${ }^{5}$. Pośród niniejszego zróżnicowania na szczególną uwagę zasługuje system organów kontroli, zajmujących się sprawdzaniem procedur nakierowanych na zagwarantowanie efektywnego i oszczędnego wydatkowania środków publicznych (zamówień publicznych) ${ }^{6}$. Do niniejszej grupy należy zaliczyć organy (podmioty) wewnętrznego kontrolowania, a mianowicie: zamawiających (w ramach tzw. samokontrolowania), wykonawców oraz Prezesa Urzędu Zamówień publicznych (dalej Prezes UZP) oraz podmioty (organy) tzw. zewnętrznej kontroli, m.in. Najwyższą Izbę Kontroli (NIK) czy też regionalne izby obrachunkowe (RIO). Uwidocznieniu dysfunkcji w ich działalności sprawdzającej (z punktu widzenia rezultatów pokontrolnych i osiągania stanu przestrzegania zasad związanych z udzieleniem zamówienia publicznego przez ich uczestników) poświęcone jest niniejsze opracowanie. Dzięki niemu możliwe stanie się wyprowadzenie wniosków na temat aktualnego obrazu działalności kontrolnej rynku zamówień publicznych i jej faktycznego oddziaływania na zagwarantowanie prawidłowości procedur związanych z udzielaniem zamówienia na realizację dostawy, usługi czy też roboty budowanej. Będzie to stanowiło asumpt dla uwidocznienia potrzeby zmian i zwrócenia się ku działalności nadzorczej - działalności ingerującej, zarządzającej, zatwierdzającej i przede wszystkim usuwającej nieprawidłowości . Działalności posługującej się instrumentami władczego oddziaływania.

\section{Postulaty prawidłowego kontrolowania}

Punktem wyjścia dla charakteryzacji działalności kontrolnej rynku zamówień publicznych jest wyodrębnienie założeń prawidłowej kontroli administracji publicznej. Chodzi w tym wypadku o postulaty ogólne, formułowane w całkowitym uniezależnieniu od podmiotu kontrolującego, niezależnie od kontrolowanego obszaru badawczego, na którym skupiane są czynności sprawdzająco-ocenne. Wedle J. Jagielskiego prawidłowa działalność kontrola (wywiązująca się ze swojej roli i zadań)

${ }^{4}$ A. Sylwestrzak, wyd. cyt., s. 7.

${ }^{5}$ Zob. J. Jagielski, wyd. cyt., s. 78.

${ }^{6}$ Zob. K. Puchacz, Kontrola zamówien publicznych, Wrocław 2010, s. 12 i 19.

${ }^{7}$ Zob. S. Duszniak, Terminologia z zakresu czynności nadzorczych i kontrolnych, Gazeta Administracyjna 1948, nr 1-2, s. 58, podaję za: C. Kociński (red.), Nadzór administracyjny. Od prewencji do weryfikacji, Wrocław 2006, s. 97. 
cechuje się obiektywizmem i bezstronnością ${ }^{8}$. Należyte zaś kompetencje podmiotu kontrolującego mają gwarantować jej sprawność i efektywność 9 . Podobnych założeń można poszukiwać w poglądach E. Ochendowskiego oraz J. Zimmermanna podnoszących kwestie bezstronności, fachowości, aktywności i efektywności odpowiedniego kontrolowania ${ }^{10}$. Celowość działalności kontrolnej skoncentrowana na usunięciu lub też na zminimalizowaniu zjawisk niepożądanych (patologicznych) oraz na zapobieganiu ich powtarzaniu się w przyszłości wymaga, aby całokształt mechanizmów kontrolnych (podmiotowych i przedmiotowych) był odpowiedni proporcjonalny do obszaru kontrolowanego. J. Boć negatywnie podchodzi do zjawiska nadmiernego rozrostu kontroli, który sprowadza się zdaniem tego autora do zwiększenia liczby podmiotów (jednostek kontrolujących), bądź też ich aparatu wykonawczego, zwiększenia rodzajów kontroli czy też nadmiernego rozszerzenia zasięgu kontroli ${ }^{11}$. Odmienne stanowisko zajmuje J. Zimmermann, podkreślając, że aby administracja publiczna mogła działać prawidłowo, powinna być kontrolowana przy użyciu rozmaitych kryteriów, przez zróżnicowane podmioty i z inicjatywy różnych organów ${ }^{12}$. Celowość działalności kontrolnej nie może sprowadzać się wyłącznie do zapewnienia zgodności z prawem kontrolowanego zachowania, badanej struktury czy też istniejącego stanu rzeczy. Jej prawidłowość pozostaje w ścisłym z związku z założeniem o konieczności występowania odpowiedniej jakości czynności sprawdzających oraz z zachowaniem terminowości postępowań kontrolerów. Prawidłowo funkcjonujący system organów kontroli opiera się na uporządkowaniu, na współdziałaniu i koordynacji, przy jednoczesnym zróżnicowaniu i niepowtarzaniu zachowań kontrolnych przez poszczególnych sprawdzających. Skuteczna i efektywna kontrola może sprzyjać osłabianiu zjawisk patologicznych oraz wzmacniać racjonalność wydatkowania funduszy publicznych ${ }^{13}$, pod warunkiem że spełnia ona wymagania prawidłowego weryfikowania.

$\mathrm{Z}$ pewnością $\mathrm{w}$ obszarze kontrolowania zamówień publicznych uwidacznia się wielość podmiotów kontrolujących, jak również wykorzystywanie rozmaitych kryteriów kontroli. $Z$ tego też względu możemy mówić o decentralizacji systemu zamówień publicznych ${ }^{14}$. W swoim założeniu ma to zapewniać prawidłowość prze-

${ }^{8}$ Zob. poglądy J. Jagielskiego: J. Boć (red.), Prawo administracyjne, Wrocław 2010, s. 382 oraz J. Zimmermann, Prawo administracyjne, Warszawa 2008, s. 405 i nast.

${ }^{9}$ Tamże. Zbliżone stanowisko reprezentuje A. Panasiuk - zob. A. Panasiuk, Czy kontrola może szkodzić?, [w:] T. Kocowski, J. Sadowy (red.), Kontrola zamówień publicznych, Wrocław-Warszawa 2013, s. 59 i nast.

${ }^{10}$ Zob. E. Ochendowski, Prawo administracyjne, Torun 2006, s. 420 i nast.

${ }^{11}$ Zob. J. Boć, wyd. cyt., s. 385.

12 J. Zimmermann, wyd. cyt., s. 402.

${ }^{13}$ Zob. S. Babiarz, Prawo zamówień publicznych. Komentarz, wyd. III, System Informacji Prawnej Lex, https://sip.lex.pl/\#/commentary/587535228/197739/babiarz-stefan-i-in-prawo-zamowienpublicznych-komentarz-wyd-iii?cm=RELATIONS, data pobrania: 10.10.2018.

${ }^{14}$ Zob. J. Pieróg, Prawo zamówień publicznych. Komentarz, System Informacji Prawnej Legalis, http://sip.legalis.pl/document-view.seam?documentId=mjxw62zogi3damjxge3dqni, data pobrania: 09.10.2018. 
biegu procedury oraz stanowić gwarancję przestrzegania w jej obrębie zasad związanych z udzieleniem zamówienia, szczególnie zaś: reguły uczciwej konkurencji oraz równego traktowania wykonawców (zasadę niedyskryminacji). Niewątpliwe na potrzeby dokonania jednoznacznej oceny niniejszego zjawiska (rozrostu kontroli) w obszarze udzielania zamówień publicznych konieczne jest (niezależnie od indywidualnej charakterystyki działalności każdego podmiotu kontrolującego z osobna) zwrócenie uwagi na aspekt harmonizacji (współdziałania, koordynacji czynności kontrolnych poszczególnych kontrolerów). Nie można bowiem mówić o występowaniu pozytywnych następstw kontrolowania występującego obok siebie, prowadzonego przez różne podmioty, na podstawie tych samych kryteriów ocennych, ale przynoszącego odmienne (czy wręcz przeciwne) rezultaty. „System kontroli zamówień publicznych powinien być logiczny, a zatem działalność organów kontroli nie powinna się wzajemnie powielać i powinna być zharmonizowana ${ }^{15}$ ". Nie bez znaczenia $\mathrm{w}$ procesie oceniania działalności kontrolnej nad rynkiem zamówień publicznym pozostaje kwestia prawidłowego interpretowania i należytego stosowania kryteriów, które zostały prawnie przydzielone poszczególnym kontrolerom w ich działalności kontrolnej. Słusznie podkreśla J. Zimmermann, że organy realizujące poszczególne kompetencje kontrolne powinny przestrzegać granic przypadających im w działaniu mierników postępowania, a w razie ich nieostrego formułowania powinny dokonywać starannej, wielopłaszczyznowej ich wykładni ${ }^{16}$.

\section{Kontrola wewnętrzna udzielania zamówień publicznych}

Doktrynalny podział działalności kontrolnej na wewnętrzną i zewnętrzną opiera się na usytuowaniu podmiotu kontrolującego względem kontrolowanego. Jeżeli bowiem kontrolujący jest umiejscowiony wewnątrz układu strukturalnego - wewnątrz aparatu obejmującego swymi rami również kontrolowanego, wówczas mówimy o kontrolowaniu wewnętrznym. To prowadzi do konstatacji, że prowadzenie badania przez podmiot usytuowany na zewnątrz, poza strukturą organizacyjną, do której przynależy jednostka kontrolowana, czyni z kontrolera i jego działalności aktywność zewnętrzną. Co istotne, tego rodzaju kwalifikacja ma zastosowanie również w zakresie kontrolowania zamówień publicznych, a ściślej mówiąc - w zakresie kontrolowania postępowań związanych z ich udzielaniem. Innego rodzaju musi być jednak jego interpretacja. W obrębie bowiem systemu zamówień publicznych nie można mówić o występowaniu pewnego rodzaju aparatu, a co najwyżej o określonego rodzaju uczestnictwie w procedurze związanej ze zlecaniem realizacji usługi, dostawy czy też roboty budowlanej. To jednak w żaden sposób nie wpływa na dopuszczalność dokonania podziału na kontrolowanie zewnętrzne i wewnętrzne w odniesieniu do

${ }^{15}$ Zob. P. Szustakiewicz, Czy istnieje system kontroli zamówień publicznych, [w:] T. Kocowski, J. Sadowy (red.), Kontrola zamówień publicznych, Wrocław-Warszawa 2013.

${ }^{16}$ J. Zimmermann, wyd. cyt., s. 403. 
omawianej dziedziny (zamówień publicznych). A interpretacja niniejszego podziału musi odwoływać się do aspektu regulacyjnego. Kontrolowanie wewnętrzne opiera się bowiem na działalności podmiotów, która została uregulowana treścią Ustawy z dnia 29 stycznia 2004 r. Prawo zamówień publicznych ${ }^{17}$ (dalej u.p.z.p.). Chodzi w tym wypadku o działalność zamawiającego, wykonawców, Krajowej Izby Odwoławczej oraz Prezesa UZP.

W myśl art. 152 ust. 1 u.p.z.p. Prezes UZP jest centralnym organem administracji rządowej właściwym w sprawach zamówień publicznych. Brzmienie niniejszej regulacji w sposób enigmatyczny wyznacza właściwość rzeczową organu, determinując przy tym szeroki zakres kompetencji (co do zasady w większości przypadków czynności organizatorskich) wyodrębnionych szczegółowo na płaszczyźnie art. 154 u.p.z.p. Pośród niniejszych kompetencji istotne znaczenie ma działalność kontrolna wyrażająca się m.in. w czuwaniu nad przestrzeganiem zasad systemu zamówień publicznych oraz w dokonywaniu analizy funkcjonowania zamówień publicznych.

Odwołując się do meritum prowadzonych rozważań należy wskazać, że podstawowym zarzutem kierowanym pod adresem zakresu działania Prezesa UZP jest właśnie działalność kontrolna, a ściślej - tylko działalność kontrolna, jak również dopuszczalność przypisania jemu jedynie statusu organu kontroli, a nie organu nad$z{ }^{18}$. Dostrzegalne jest bowiem zjawisko rozszczepienia jego funkcji i odejście od uprawnień władczych oraz regulacyjnych przy jednoczesnym zachowaniu ich administracyjnego charakteru ${ }^{19}$. Z samego bowiem doktrynalnego rozróżniania kategorii kontroli i nadzoru wynika, że pomimo wyraźnego związku pomiędzy zagadnieniami i tożsamej celowości istnienia (zgodność z wzorcami prawnie i pozaprawnie ukształtowanymi), nadzorowanie jest zabiegiem lepszym, skuteczniejszym i efektywniejszym. Nadzór oznacza bowiem prawną dopuszczalność oddziaływania przez podmiot go realizujący na działalność podporządkowanych lub też jedynie weryfikowanych organów lub instytucji ${ }^{20}$. Prezes UZP nie jest organem nadzoru nad rynkiem zamówień publicznych, nie nadzoruje również postępowań o udzielenie za-

${ }^{17}$ Dz. U. z 2017, poz. 1579 ze zm.

${ }^{18}$ Odmienne stanowisko prezentuje J. Jerzykowski, wskazując, że przesunięcie punktu ciężkości z nadzoru na działalność kontrolną Prezesa UZP należy ocenić pozytywnie, bo ułatwia to prowadzenie postępowania - zob. J. Jerzykowski, [w:] M. Stachowiak, J. Jerzykowski, W. Dzierżanowski, T. Kwieciński, W. Łysakowski, Prawo zamówień publicznych. Komentarz, wyd. 2, Warszawa 2006, s. 334.

${ }^{19}$ Zob. też A.E. Norek, Prawo zamówień publicznych. Komentarz, Warszawa 2005, s. 206, zob. też stanowisko K. Horubskiego - K. Horubski, Publiczno- i prywatnoprawne elementy zamówień publicznych, Państwo i Prawo, 2009, nr 7, s. 78 oraz s. 83-84, zob. też S. Babiarz, wyd. cyt., System Informacji Prawnej Lex, https://sip.lex.pl/\#/commentary/587535228/197739/babiarz-stefan-i-in-prawozamowien-publicznych-komentarz-wyd-iii?cm=RELATIONS, data pobrania: 10.10.2018.

${ }^{20}$ Zob. W. Dawidowicz, Zagadnienia ustroju administracji państwowej w Polsce, Warszawa 1970, s. 34 i n. Zob. też postanowienie WSA w Warszawie z dnia 29 grudnia 2005 r., III SA/ Wa 3202/05, http://orzeczenia.nsa.gov.pl/doc/52462FB06F, data pobrania: 08.10.2018 oraz wyrok WSA w Warszawie z dnia 28 lutego 2008 r., V SA/Wa 2614/07, http://orzeczenia.nsa.gov.pl/doc/A5CD9DA295, data pobrania: 08.10.2018. 
mówień, o których mowa na gruncie art. 2 pkt 7a u.p.z.p., mimo iż jest centralnym organem w sprawie zamówień publicznych. Tego rodzaju twierdzenie opiera się na tzw. tradycyjnym interpretowaniu nadzoru jako kompetencji związanych z możliwością władczego ingerowania - wpływania na kontrolowanego za pomocą decyzji administracyjnej, która w swej istocie ma stanowić wyraz akceptacji ze strony organu, jego zgody czy też potwierdzenia dla ocenianego stanu rzeczy. Szerokie zaś ujęcie działalności nadzorczej, wychodzące poza (ograniczające się do formy decyzji administracyjnej) oddziaływanie na tzw. drugą stronę, pozwala na wyodrębnienie również czynności nadzorczych Prezesa UZP. To implikuje twierdzenie, w świetle którego podejmowane $\mathrm{w}$ ciągu lat dążenia do ograniczenia władczego charakteru działalności Prezesa UZP, nie wyeliminowały wszelkiego rodzaju czynności organu, za pomocą których ma on możliwość wpływania na sytuację kontrolowanego. Chodzi w tym wypadku o: możliwość wystąpienia do sądu o unieważnienie umowy o udzielenie zamówienia publicznego, o zawiadomienie rzecznika dyscypliny finansów publicznych o naruszeniu dyscypliny finansów publicznych, o nałożenie kary pieniężnej ${ }^{21}$. Wszystkie przedstawione powyżej środki nadzorcze przysługują w sytuacji ujawnienia naruszenia przepisów u.p.z.p., z tym jednak że tylko jeden z nich a mianowicie kara pieniężna stanowi przejaw oddziaływania bezpośredniego organu na podmiot kontrolowany ${ }^{22}$. Zarówno bowiem w zakresie wnioskowania o unieważnienie umowy, jak i w przypadku zawiadomienia o naruszeniu dyscypliny finansów publicznych uwidacznia się jedynie pośrednie oddziaływanie Prezesa UZP na zachowanie kontrolowanego. Ostateczna bowiem decyzyjność, ostateczne rozstrzygnięcie w przedmiocie swoistego „ukarania” zostało przekazane przez ustawodawcę

${ }^{21}$ Zamawiający, który: udziela zamówienia z naruszeniem przepisów ustawy określających przesłanki stosowania trybów udzielania zamówienia: negocjacji bez ogłoszenia, z wolnej ręki lub zapytania o cenę, bez wymaganego ogłoszenia, bez stosowania ustawy, dokonuje zmian w zawartej umowie z naruszeniem przepisów ustawy, podlega karze pieniężnej. Karze pieniężnej podlega również zamawiający, który: określa warunki udziału w postępowaniu o udzielenie zamówienia w sposób, który utrudnia uczciwą konkurencję, opisuje przedmiot zamówienia w sposób, który utrudnia uczciwą konkurencję, prowadzi postępowanie o udzielenie zamówienia z naruszeniem zasady jawności, nie przestrzega terminów określonych w ustawie, wyklucza wykonawcę z postępowania o udzielenie zamówienia z naruszeniem przepisów ustawy określających przesłanki wykluczenia, odrzuca ofertę z naruszeniem przepisów ustawy określających przesłanki odrzucenia oferty, dokonuje wyboru najkorzystniejszej oferty z naruszeniem przepisów ustawy, jeżeli naruszenie to ma wpływ na wynik postępowania o udzielenie zamówienia (art. 200 u.p.z.p.).

${ }^{22}$ Karę pieniężną nakłada Prezes UZP w drodze decyzji administracyjnej. Prezes UZP nie nakłada kary pieniężnej, jeżeli w związku z naruszeniem przepisu ustawy KIO lub sąd nałożyli karę finansową. Decyzji o nałożeniu kary pieniężnej nie można nadać klauzuli natychmiastowej wykonalności. Warto w tym miejscu zauważyć, że Prezes UZP nie jest jedynym organem, który w świetle uregulowań u.p.z.p. dysponuje uprawnieniem do nałożenia kary finansowej. Tego rodzaju legitymacja przysługuje również KIO (art.193 oraz 194 u.p.z.p.). Co istotne, tego rodzaju stan rzeczy świadczy nieodzownie o osłabieniu pozycji Prezesa jako organu, któremu przyznano kompetencje nadzorcze. Nie jest bowiem jedynym, który został wyposażony w prawo do władczego ingerowania za pomocą wymierzenia pewnego rodzaju dolegliwości pieniężnej, finansowej. 
na rzecz organu wymiaru sprawiedliwości oraz KIO. Całokształt przedstawionych rozważań w sposób wyraźny determinuje jedynie iluzoryczny charakter działalności nadzorczej organu w jej klasycznym rozumieniu. Tzw. władcze i dające pewność pożądanej reakcji ze strony kontrolowanego działanie Prezesa UZP zostało zastąpione uprawnieniami tworzącymi jedynie dopuszczalność uwidocznienia stwierdzonych nieprawidłowości i „postulowanie” konieczności przeprowadzenia pożądanych zmian. Owego osłabionego statusu organu kontrolującego nie jest w stanie zniwelować fakt jego nadzorowania przez Prezesa Rady Ministrów, co jak wskazuje P. Szustakiewicz, ma na celu podkreślenie, że ,... ustawodawca nadał dużą rangę kwestii skuteczności funkcjonowania systemu zamówień publicznych"23.

W ich obrębie (w obrębie uprawnień kontrolnych organu), m.in. ze względu na sposób uregulowania przez ustawodawcę, możliwe staje się wypunktowanie pewnego rodzaju niedociągnięć, nieprawidłowości, skutkujących osłabieniem zjawiska kontroli jako zespołu czynności służących uzdrowieniu „zastanego”, a niezgodnego z zasadami udzielania zamówień publicznych stanu rzeczy. A zatem sama istota działalności kontrolnej (słabo oceniana w zderzeniu z uprawnieniami nadzorczymi) nie stanowi jedynej bolączki w obszarze kontrolowania zamówień publicznych przez Prezesa UZP. Wątpliwości mogą budzić również następujące aspekty kontrolowania doraźnego i uprzedniego organu:

1. Ograniczenia terminowe, zakresowe oraz miejscowe w dzialalności kontrolnej Prezesa UZP (w obrębie tzw. kontrolowania właściwego i formalnego). Dotyczą one rozmaitych form i rodzajów kontrolowania Prezesa UZP. O terminowym ograniczeniu można mówić w zakresie tzw. kontroli doraźnej. Zgodnie z brzmieniem art. 165 u.p.z.p. Prezes UZP może wszcząć z urzędu lub na wniosek kontrolę doraźną w przypadku uzasadnionego przypuszczenia, że w postępowaniu o udzielenie zamówienia doszło do naruszenia przepisów ustawy, które mogło mieć wpływ na jego wynik. Prezes UZP wszczyna kontrolę doraźną na wniosek instytucji zarządzającej. Dopuszczalność przedmiotowego kontrolowania jest obwarowana terminem, albowiem stosownie do ust. 2 art. 165 u.p.z.p. wszczęcie kontroli doraźnej (jako kontroli następczej) może nastąpić nie później niż w ciągu 4 lat od dnia zakończenia postępowania o udzielenie zamówienia publicznego. Co istotne, przez pryzmat wspomnianej powyżej regulacji można pozornie dopatrywać się pejoratywnego charakteru ustawowego ograniczenia. Wątpliwości bowiem rodzi nie sam fakt ograniczenia, nie wyznaczenie terminu przez ustawodawcę, ale długość tego terminu (co więcej, nie za krótka, ale wręcz przeciwnie - za długa). Sama nomenklatura, samo nazewnictwo, którym posłużył się ustawodawca dla wyznaczenia niniejszej kategorii kontrolowania - kontrolowania doraźnego, błędnie sugeruje, że jej podejmowanie ma miejsce na bieżąco - wtedy, kiedy zachodzi taka potrzeba, jako kontroli w pewnym stopniu faktycznej, bo prowadzonej $\mathrm{w}$ trakcie realizacji czynności, w żadnym razie nieplanowanej, ale

${ }^{23}$ Zob. P. Szustakiewicz, Kontrola zamówień publicznych. Zagadnienia praktyczne, Warszawa 2011, s. 37-38. 
o ściśle represyjnym charakterze ${ }^{24}$ Tego rodzaju nazewnictwo ma determinować jej szczególne znaczenie oraz szczególną wagę. Nie jest bowiem tajemnicą, że najlepszą formą kontrolowania jest badanie dokonywane w trakcie konkretnej aktywności kontrolowanego, w trakcie podejmowania przez niego stosownych decyzji. Pozwala bowiem w sposób najpełniejszy ustalić nieprawidłowości i zapobiec ich natychmiastowemu powtarzaniu. Kontrola powinna być prowadzona na bieżąco, albowiem prawidłowo funkcjonujący system zamówień publicznych nie przewiduje, a czasami wręcz eliminuje, możliwości ponawiania czy też ,uleczania” czynności w postępowaniu o udzielenie zamówienia publicznego ${ }^{25}$. O ograniczeniu czasowym można mówić również w kontekście kontrolowania uprzedniego, którego krótki termin prowadzenia ${ }^{26}$ (jak podnosi doktryna) wymaga silnego skoncentrowania uwagi kontrolera na potrzebie szybkiego wykrycia istniejących nieprawidłowości. W myśl art. 171 ust. 3 u.p.z.p. doręczenie informacji o wyniku kontroli następuje nie później niż w terminie 14 dni od dnia doręczenia materiałów przeznaczonych do weryfikacji, a w zakresie kontroli szczególnie skomplikowanej nie później niż w ciągu 30 dni od dnia ich doręczenia. Ograniczenie zakresowe uwidacznia się w kontekście kontrolowania uprzedniego. Jest ono - jak wskazuje ustawodawca - podejmowane obligatoryjnie, ale dopuszczalność jego prowadzenia jest warunkowana wartością zamówienia albo też umowy ramowej. W myśl art. 169 ust. 2 u.p.z.p. Prezes UZP przeprowadza kontrolę udzielanych zamówień przed zawarciem umowy, jeżeli wartość zamówienia albo umowy: dla roboty budowlanej jest równa wyrażonej w złotych równowartości kwoty 20000000 euro lub ją przekracza, dla dostaw lub usług zaś jest równa wyrażonej w złotych równowartości kwoty 10000000 euro lub ją przekracza. Z kolei wspomniane powyżej ograniczenie miejscowe odnosi się do przestrzeni (do miejsca) przeprowadzania czynności sprawdzająco-ocennych. Kontrolę (doraźną oraz uprzednią) przeprowadza się w siedzibie UZP, chyba że kontrolowanie obejmuje dokumentację zawierającą informacje niejawne (o klauzuli „ściśle tajne” lub też „tajne”, wówczas kontrolowanie może odbywać się na miejscu - tj. w siedzibie zamawiającego). Kontrolowanie poza siedzibą zmawiającego, mimo iż zasługujące na pozytywną ocenę (m.in. z racji oszczędności i jednocześnie obniżonych kosztów występujących po stronie kontrolera) może rodzić zagrożenia w postaci niedostrzegania wszystkich faktycznie występujących nieprawidłowości. Niniejszemu stanowisku nie jest w stanie przeciwdziałać mniejszy wysiłek dostrzegalny po stronie aktywnie działającego kontrolera oraz co do zasady krótszy okres na realizację czynności sprawdzających,

${ }^{24}$ Takim określeniem wskazującym na represyjny charakter posłużył się: J. Gola - zob. J. Gola, Kontrola Prezesa Urzędu Zamówień Publicznych jako instrument zapobiegania korupcji w administracji publicznej, [w:] T. Kocowski, J. Sadowy (red.), Kontrola zamówień publicznych, Wrocław-Warszawa 2013, s. 140.

${ }^{25}$ Zob. A. Mituś, Kontrola zarządcza a udzielanie zamówień publicznych - zarys problematyki, [w:] T. Kocowski, J. Sadowy (red.), Kontrola zamówień publicznych, Wrocław-Warszawa 2013, s. 270.

${ }^{26}$ Zob. P. Szustakiewicz, Kontrola ..., s. 46. 
wynikający z braku konieczności przemieszczania się do siedziby kontrolowanego. A.E. Norek wskazuje, że ustawodawca nie dopuszcza w tym wypadku odstępstwa nawet wówczas, gdyby wiązało się ono z przyśpieszeniem procedury kontrolnej ${ }^{27}$. Jedyny dopuszczalny wyjątek opiera się na szczególnej kategorii informacji objętych klauzulą ,ś́ciśle tajne” oraz „tajne”. Bezpośrednie, tzw. naoczne zapoznawanie się $\mathrm{z}$ otoczeniem, z miejscem działania zamawiającego, z zatrudnionymi u zamawiającego pracownikami przynosi więcej korzyści aniżeli wyłączne opieranie się w swych działaniach sprawdzających na doręczonej przez zamawiającego dokumentacji.

\section{Uzależnienie kontrolowania doraźnego od uzasadnionego przypuszcze-} nia, że w postępowaniu doszło do naruszenia przepisów ustawy, które mogło mieć wpływ na jego wynik (art. 161 ust. 2 u.p.z.p.). Posłużenie się przez ustawodawcę nie do końca wyraźnie określonym, a charakterystycznym dla postępowania karnego sfomułowaniem czyni trudnym sprecyzowanie, kiedy dokładnie staje się konieczne przeprowadzenie kontrolowania doraźnego. Uzasadnione przypuszczenie z pewnością oznacza brak pewności co do naruszenia uregulowań u.p.z.p., ale też $z$ drugiej strony jest równoznaczne $z$ dużym prawdopodobieństwem jego zaistnienia. Jest ono dodatkowo wzmocnione posiadanymi dowodami przemawiającymi za racją podmiotu „przypuszczającego".

\section{Zaopatrzenie Prezesa UZP w jedyne kryterium - kryterium zgodności} $\mathbf{z}$ ustawą. W myśl art. 161 ust. 2 u.p.z.p. celem kontroli jest sprawdzenie zgodności postępowania o udzielenie zamówienia z przepisami ustawy. $\mathrm{Na}$ tej płaszczyźnie uwidacznia się ograniczenie kompetencyjne organu w zakresie prowadzonej działalności kontrolnej. Dopuszczalność weryfikowania postępowań, a ściślej mówiąc - zachowań zamawiającego, sprowadza się do weryfikowania ich zgodności z przepisami u.p.z.p. oraz (pomimo braku wyraźnego wskazania przez ustawodawcę) z aktami wykonawczymi wydanymi na jej podstawie ${ }^{28}$. Tym samym ustawodawca ogranicza kompetencyjność badawczą organu do jednego tylko aktu, aktu stanowiącego jedynie fragment większej całości - całego systemu prawa, a w tym również innych aktów prawnych mających zastosowanie w odniesieniu do aspektu udzielania zamówień publicznych (do dysponowania funduszami publicznymi). Prezes UZP „(...) nie może kwestionować potrzeby udzielenia zamówienia publicznego lub sprawdzać, czy środki finansowe są wydatkowane oszczędnie, celowo i racjonalnie"29. Wedle A. Skubiszak-Kalinowskiej oraz E. Wiktorowskiej kontrolowanie Prezesa UZP zmierza do ustalenia prawdy materialnej i sformułowania w tym zakresie stosownych

${ }^{27}$ Zob. A.E. Norek, Prawo zamówień publicznych. Komentarz, wyd. III, System Informacji Prawnej Lex, https://sip.lex.pl/\#/commentary/587528796/341913/norek-emil-a-prawo-zamowien-publicznychkomentarz-wyd-iii?cm=RELATIONS, data pobrania: 09.10.2018.

${ }^{28}$ Zob. K. Marak, Kontrola udzielania zamówień publicznych $w$ świetle instytucji kontroli i nadzoru w materialnym prawie administracyjnym, [w:] T. Kocowski, J. Sadowy (red.), wyd. cyt., s. 153.

${ }^{29}$ Zob. J. Pieróg, wyd. cyt.; System Informacji Prawnej Legalis, http://sip.legalis.pl/document-view.seam?documentId=mjxw62zogi3damjxge3dqni, data pobrania: 09.10.2018. 
zarzutów naruszenia prawa ${ }^{30}$. Brzmienie przywołanej regulacji uwidacznia również pozornie niedostrzegalne ograniczanie jeszcze innego rodzaju, a mianowicie ograniczenie zakresowe czynności kontrolnych Prezesa UZP. Przywołując raz jeszcze zawartość regulacji: ,celem postępowania jest sprawdzenie zgodności postępowania o udzielenie zamówienia (...)", należy stwierdzić, że to w związku z zawartością art. 2 pkt 7a eliminuje z legitymacji kontrolnej organu rezultat prowadzonej procedury - umowę na realizację dostawy, usługi czy też roboty budowlanej. Adekwatnie do zawartości pkt 7a przez objęte procesem kontrolowania postępowanie o udzielenie zamówienia publicznego należy rozumieć postępowanie wszczynane w drodze publicznego ogłoszenia o zamówieniu lub przesłania zaproszenia do składania ofert albo przesłania zaproszenia do negocjacji w celu dokonania wyboru oferty wykonawcy, z którym zostanie zawarta umowa w sprawie zamówienia publicznego, lub w przypadku trybu zamówienia $\mathrm{z}$ wolnej ręki - wynegocjowania postanowień takiej umowy. Nie jest to jednak różnoznaczne z całkowitym wykluczeniem spod procesu kontrolowania rezultatu postępowania - umowy, i w zdecydowanym stopniu świadczy o jedynie quasi-ograniczeniu przedmiotowym kompetencji organu. Zgodnie $\mathrm{z}$ wszechobowiązującą zasadą jawności zwieńczenie postępowania w sprawie o udzielenie zamówienia publicznego podlega m.in. społecznemu kontrolowaniu w ramach dostępu do informacji publicznej. Jest ono realizowane zarówno w trybie uregulowanym u.p.z.p., jak i na podstawie Ustawy z dnia 6 września 2001 r. o dostępie do informacji publicznej ${ }^{31}$. Ponadto Prezesowi UZP przysługuje uprawnienie do występowania z powództwem o unieważnienie całości umowy albo też jej części. To jednak nie zmienia faktu, że samemu bezpośredniemu kontrolowaniu Prezesa UZP nie podlega rezultat procedury ani poprawność wykonania zamówienia przez wyłonionego w postępowaniu wykonawcę ${ }^{32}$. Również wszelkiego rodzaju konflikty powstałe na niniejszym tle, a zachodzące pomiędzy wykonawcą i podmiotem zamawiającym, pozostają poza kompetencją badawczą Prezesa UZP ${ }^{33}$.

\section{Wyposażenie Prezesa UZP w wyłączną legitymację do kierowania nie-} wiążących informacji o wyniku kontroli. Zakończeniem kontroli doraźnej oraz uprzedniej jest doręczenie zamawiającemu informacji o wyniku kontroli. Zawiera ona co do zasady informacje na temat postępowania będącego przedmiotem kon-

${ }^{30}$ Zob. I. Skubiszak-Kalinowska, E. Wiktorowska, Prawo zamówień publicznych. Komentarz, System Informacji Prawnej Lex, https://sip.lex.pl/\#/commentary/587754976/570143/skubiszak-kalinowska-irena-wiktorowska-ewa-prawo-zamowien-publicznych-komentarz-aktualizowany?cm=RELA TIONS, data pobrania: 10.10.2018.

${ }^{31}$ Dz. U. z 2018 r., poz. 1330 ze zm., zob. wyrok KIO z dnia 7 marca 2012 r., sygn.. akt. KIO 384/12， https://sip.lex.pl/\#/jurisprudence/538000750/1?directHit=true\&directHitQuery=KIO\%20384 2F12, data pobrania: 12.10.2018 wyrok KIO z dnia 3 lipca 2012 r., sygn. akt. KIO 1275/12, https://sip.lex. $\mathrm{pl} / \#$ /jurisprudence/538083041/1?directHit=true\&directHitQuery $=\mathrm{KIO} \% 201275 \sim 2 \mathrm{~F} 12$, data pobrania: 12.10.2018.

${ }^{32}$ Zob. E. Garbala, Kontrola zamówień publicznych prowadzona przez Prezesa Urzędu Zamówień Publicznych, FK, 2008, nr 1-2, s. 69.

33 Tamże. 
trolowania oraz informację o stwierdzonych naruszeniach bądź też o ich braku (art. 166 ust. 1 oraz art. 171 ust. 1 u.p.z.p.). Ujemnych następstw wynikających z niewiążącego charakteru omawianej dokumentacji nie jest w stanie zniwelować użyty przez ustawodawcę zwrot „w szczególności”, który uposaża Prezesa UZP w prawo do wyraźniejszego zobrazowania wyników kontroli u konkretnego zamawiającego. Informowanie bowiem co do zasady sprowadzające się do wytykania błędów i nieprawidłowości nie jest w stanie doprowadzić do usprawnienia badanej działalności, jeśli tylko odmienna jest wola (aspiracje) podmiotu kontrolowanego. $Z$ drugiej jednakże strony, nie należy zapominać o wspominanym już uprawnieniu Prezesa UZP w przedmiocie wnioskowania o unieważnienie umowy, które mimo iż nie gwarantuje osiągnięcia pożądanego przez wnioskodawcę stanu rzeczy, w swej istocie może uchodzić za istotną przeciwwagę dla negatywnego nastawienia względem niewiążących wyników pokontrolnych organu.

\section{Związanie Prezesa UZP opinią Krajowej Izby Odwoławczej (dalej zw.} KIO) odnoszącą się do zastrzeżeń zgłoszonych przez kontrolowanego względem wyniku kontroli doraźnej czy też uprzedniej. Negatywnie oceniany brak kompetencji nadzorczych uwidacznia się szczególnie w zakresie postępowania pokontrolnego, a ściślej zaś określając - w przydzieleniu uprawnienia do ostatecznego rozstrzygnięcia o wynikach kontroli KIO. Od wyniku bowiem kontrolowania doraźnego zamawiającemu przysługuje prawo do zgłoszenia umotywowanych zastrzeżeń w ciągu 7 dni od dnia doręczenia informacji o wyniku kontroli. W przypadku ich nieuwzględnienia sprawa podlega zaopiniowaniu przez KIO. Opinia KIO jest wiążąca dla Prezesa i - co ważne z punktu widzenia tzw. społecznego kontrolowania - nie podlega zaskarżeniu ${ }^{34}$. Tym samym podmiot najbardziej zainteresowany kontrolowany, nie może ubiegać się zweryfikowanie rozstrzygnięcia KIO na drodze sądowej. Celowości niniejszego stanu rzeczy należy upatrywać w charakterze i pozycji podmiotu opiniodawczego. Bez wątpienia przyznanie tego rodzaju legitymacji podmiotowi niezależnemu, podmiotowi niebędącemu uczestnikiem postępowania kontrolnego o ściśle mediacyjnych charakterze ma w swoim założeniu gwarantować bezstronność i obiektywizm w działalności kontrolnej Prezesa UZP. Nie należy jednakże przy tym zapominać, że nie tylko przekreśla jego rolę jako organu nadzorczego, ale i osłabia jego status jako organu kontrolującego stan zgodności z prawem postępowań o udzielenie zamówienia publicznego ${ }^{35}$.

Kontrolowanie wewnętrzne obejmuje również działalność samych wykonawców biorących udział w postępowaniu o udzielenie zamówienia publicznego. Podobnie jak tzw. samokontrola podmiotu zamawiającego ma istotne znaczenie, albowiem to właśnie uczestnicy postępowania są najbliżej procedury, którą znają i dzięki narzędziom prawnym pozostającym w ich dyspozycji mogą eliminować nieprawi-

${ }^{34}$ Zob. E. Garbala, wyd. cyt.; T. Kocowski, J. Sadowy (red.), wyd. cyt., s. 339.

${ }^{35}$ Zob. poglądy E. Przeszło w zakresie istniejącego sytemu kontrolowania zamówień publicznych:

E. Przeszło, Kontrola udzielania zamówień publicznych, Poznań 2013, s. 1 i nast. 
dłowości przed wkroczeniem tzw. kontroli właściwej, realizowanej przez podmioty ściśle kontrolne (mniej lub bardziej ograniczające się do weryfikacji zamówień publicznych). Mimo iż nie jest przez ustawodawcę określane mianem weryfikacji obywatelskiej (nie do końca gwarantującej obiektywizm i bezstronność kontrolera), wyczerpuje jej znamiona, prowadząc do pierwszoplanowej obserwacji, dokonywanej na bieżąco i zmierzającej do usprawnienia obarczonej wadami działalności zamawiającego. Chodzi w tym wypadku o społeczne kontrolowanie (indywidualne i zorganizowane) pozostające $\mathrm{w}$ ścisłym związku $\mathrm{z}$ uprawnieniem do korzystania z prawnie gwarantowanych środków ochrony prawnej, o których mowa w dziale VI u.p.z.p. Słusznie podnosi się w literaturze, że środki ochrony prawnej stanowią naczelny instrument ochrony interesów wykonawców w postępowaniach o udzielenie zamówienia publicznego, zmierzający do częściowego zniwelowania nierównorzędnej pozycji wykonawców i podmiotu zamawiającego ${ }^{36}$. Wspomagają czynności sprawdzające podmiotów zewnętrznego i wewnętrznego kontrolowania, m.in. poprzez korygowanie stwierdzonych nieprawidłowości w czasie trwania postępowania o udzielenie zamówienia publicznego, a nie po jego zakończeniu ${ }^{37}$. Biorąc jednakże pod uwagę aspekt ściśle pozaprawny - aspekt psychologiczny nawiązujący do charakteru wewnętrznego nastawienia uprawnionych względem użyteczności przysługujących środków ochrony prawnej, można by pokusić się o twierdzenie, że w wielu przypadkach powyższe stanowisko (stanowisko o ich istotnym znaczeniu) ma raczej postulatywny charakter. W grę wchodzić może w tym wypadku nieuzasadniona obawa wykonawców dotycząca korzystania z procedury odwoławczej czy też zaskarżeniowej ze względu na dalsze postępowania - z powodu możliwości zainteresowania się podobną procedurą (procedurą o udzielenie zamówienia) w przyszłości i jednocześnie wrogim - negatywnym nastawieniem podmiotu zamawiającego ${ }^{38}$. Wbrew zatem obowiązującej zasadzie niedyskryminacji, równego traktowania, do której przestrzegania są zobligowani wszyscy zamawiający, po stronie wykonawców może pojawić się poczucie niepokoju. Obawa może dotyczyć zignorowania oferty w przyszłości, odrzucenia oferty zainteresowanego realizacją usługi, dostawy czy też roboty budowlanej przez ten sam podmiot zamawiający ze względu na uprzednie korzystanie przez wykonawcę z prawa do odwołania czy też na zaskarżanie rozstrzygnięć odwoławczych. Na tej płaszczyźnie uwidacznia się wspomniana

36 Zob. E. Przeszło, Kontrola udzielania zamówień publicznych, Poznań 2013, s. 303, zob. W. Dzierżanowski, J. Jerzykowski, M. Stachowiak, Prawo zamówień publicznych. Komentarz, wyd. VII, System Informacji Prawnej Lex, https://sip.lex.pl/\#/commentary/587227424/545140/ dzierzanowski-wlodzimierz-jerzykowski-jaroslaw-stachowiak-malgorzata-prawo-zamowienpublicznych...? $\mathrm{cm}=$ RELATIONS, data pobrania: 12.10.2018. Zob. też A. Kurowska, Postępowanie odwoławcze przed KIO jako środek korygujący w postępowaniu o udzielenie zamówienia publicznego, [w:] T. Kocowski, J. Sadowy (red.), Kontrola zamówień publicznych, Wrocław-Warszawa 2013, s. 191.

37 Tamże.

${ }^{38}$ Zob. K. Wiśka-Rużewicz, Rola wykonawcy jako podmiotu kontrolującego prawidłowość udzielenia zamówienia, [w:] T. Kocowski, J. Sadowy (red.), wyd. cyt., s. 170. 
uprzednio nierównorzędność uczestników postępowania o udzielenie zamówienia publicznego, a ściślej - silniejsza pozycja strony zamawiającej. Tego rodzaju stan rzeczy, wbrew pozytywnie kreowanym założeniom o efektywności i o doniosłym znaczeniu kontroli społecznej, może negatywnie wpływać na zakres i realizację działalności społecznego weryfikowania.

Analiza środków ochrony prawnej uwidacznia istnienie integralnego związku z działalnością Prezesa UZP. Nieprzypadkowo bowiem ustawodawca wyposaża Prezesa UZP w kompetencje do zapewniania funkcjonowania systemu środków ochrony prawnej (prawa do odwołania, prawa do wniesienia skargi sądu powszechnego). Niniejsza regulacja z pewnością budzi pozytywne skojarzenia prowadzące do wnioskowania o wzmocnieniu charakteru i roli środków ochrony prawnej. Ustawodawca nie determinuje jednakże, na czym owa gwarancja funkcjonowania pochodząca ze strony Prezesa UZP miałaby polegać, a w samej procedurze związanej z odwoływaniem się czy też z zaskarżaniem czynności zamawiającego można doszukać się niedociągnięć negatywnie oddziałujących na sferę udzielania zamówień publicznych. Dokonując ich wewnętrznego uszeregowania, można zwrócić uwagę na:

1. Obwarowanie wymaganiami formalnymi i merytorycznymi ${ }^{39}$, trudnymi do przejścia dla ubiegających się o udzielenie ochrony prawnej (art. 180 ust. 3-4, art. 187 ust. 2-8 u.p.z.p., art. 198a, art. 198b u.p.z.p.). Zgodnie z brzmieniem art. 187 ust. 1 u.p.z.p. odwołanie podlega rozpoznaniu, jeżeli nie zawiera braków formalnych oraz jeżeli uiszczono od niego stosowny wpis ${ }^{40}$. Warto w tym miejscu zwrócić uwagę, że ustawowe odesłanie do uregulowań Ustawy z dnia 17 listopada 1964 r. - Kodeks postępowania cywilnego ${ }^{41} \mathrm{~W}$ przedmiocie procedury rozpatrywania skarg nie rodzi pozytywnych emocji po stronie przeciętnego obywatela, przeciętnego przedsiębiorcy ${ }^{42}$. Dla przeciętnego wykonawcy dochodzącego swoich uprawnień, niemogącego liczyć na pomoc ze strony profesjonalistów, tego rodzaju procedowanie (niezdeterminowane wyraźnie przez ustawodawcę) może wydawać się nieznane, obce, trudne w realizacji. To z kolei może w istotny sposób skutkować niechęcią w przejawianiu woli zaskarżania rozstrzygnięć, ograniczając tym samym zakres tzw.

${ }^{39}$ Zob. Wyrok KIO z dnia 20 lutego 2015 r., sygn. akt. 242/15, https://sip.lex.pl/\#/jurisprudence/ 538527321/1?directHit=true\&directHitQuery=KIO\%20242 2F15, data pobrania: 14.10.2018; Wyrok KIO z dnia 20 lutego 2015 r., sygn. akt. 1479/14, https://sip.lex.pl/\#/jurisprudence/538382330/1?direct Hit=true\&directHitQuery=KIO\%201479 2F14, data pobrania: 14.10.2018.

${ }^{40}$ Zob. Rozporządzenie Prezesa Rady Ministrów z dnia 22 marca 2010 r. w sprawie regulaminu postępowania przy rozpoznawaniu odwołań (Dz. U. z 2018 r., poz. 1092), Rozporządzenie Prezesa Rady Ministrów z dnia 15 marca 2010 r. w sprawie wysokości i sposobu pobierania wpisu od odwołania oraz rodzajów kosztów w postępowaniu odwoławczym i sposobu ich rozliczania (Dz. U. z 2018 r., poz. 972) oraz Ustawa z dnia 28 lipca 2005 r., o kosztach sądowych w sprawach cywilnych (Dz. U. z 2018 r., poz. 300).

${ }^{41}$ Dz. U. z 2018 r., poz. 1360 ze zm.

${ }^{42} \mathrm{Z}$ tego też względu na poziomie doktrynalnym mówi się o apelacyjnym charakterze skargi. Zob. K. Pieróg, wyd. cyt.; System Informacji Prawnej Legalis, http://sip.legalis.pl/document-view.seam?documentId=mjxw62zogi3damjxge3dqni, data pobrania: 10.10 .2018 . 
kontrolowania społecznego. Z drugiej jednakże strony, powtarzanie uregulowań postępowania cywilnego, dosłowne przenoszenie ich grunt u.p.z.p. nie byłoby racjonalne i zgodne z zasadami techniki prawodawczej. Celem wyważenia obu stanowisk i przy uwzględnieniu statusu obu stron przedmiotowego procesu być może w pełni prawidłowe byłoby konkretne ustawowe wyróżnienie przepisów dotyczących apelacji, które mają zastosowanie w odniesieniu do skarg na orzeczenie KIO.

2. Krótkie terminy przewidziane dla przedłożenia środków ochrony prawnej (art.182 u.p.z.p.), w niektórych przypadkach krótsze aniżeli ogólny termin na odwołanie, o którym stanowią uregulowania Ustawy z dnia 14 czerwca 1960 r. Kodeks postępowania administracyjnego ${ }^{43}$.

3. Wysokie koszty związane $\mathbf{z}$ dochodzeniem swoich praw (zob. Rozporządzenie Prezesa Rady Ministrów z dnia 15 marca 2010 r. w sprawie wysokości i sposobu pobierania wpisu od odwołania oraz rodzajów kosztów w postępowaniu odwoławczym i sposobu ich rozliczania) ${ }^{44}$.

4. Gwarantowanie co do zasady bezstronności i obiektywizmu w procesie rozpatrywania środków zaskarżania (art. 174 ust. 7 u.p.z.p.) przy jednoczesnym przyznawaniu kompetencji orzeczniczych organowi dzialającemu co do zasady jednoosobowo ${ }^{45}$. W myśl art. 188 u.p.z.p. odwołanie rozpoznaje Izba w składzie jednoosobowym. Prezes Izby może zarządzić rozpoznanie sprawy w składzie trzyosobowym, jeżeli uzna to za wskazane ze względu na szczególną zawiłość sprawy lub precedensowy jej charakter ${ }^{46}$.

Nie bez znaczenia dla prawidłowości i efektywności procesu społecznego kontrolowania (jak wskazuje doktryna) pozostaje rezygnacja przez ustawodawcę z instytucji protestu. W myśl nieobowiązującego już art. 180 u.p.z.p. ${ }^{47}$ : „Wobec czynności podjętych przez zamawiającego $\mathrm{w}$ toku postępowania oraz $\mathrm{w}$ przypadku zaniechania przez zamawiającego czynności, do której jest on obowiązany na podstawie ustawy, można wnieść pisemny protest do zamawiającego". Słusznie dochodzi do podkreślenia, że brak instytucji pozainstytucjonalnego i pozasądowego dochodzenia swoich praw w istotny sposób może ograniczać liczbę wykonawców ubiegających się o udzielenie im ochrony prawnej ${ }^{48}$. Jak wskazuje autorka, instytucja protestu stanowiła bezpośrednią formę rozstrzygania sporu pomiędzy uczestnikami postępowania: zamawiającym a wykonawcą, nie przenosząc go na drogę postępowania bardziej sformalizowanego (odwołanie) czy też w dalszej kolejności postępowania sądowego ${ }^{49}$. Mimo iż uchodził za instrument znacznie wydłużający

${ }^{43}$ Dz. U. z 2017, poz. 1257 ze zm.

${ }^{44}$ Dz. U. z 2010 r., nr 41, poz. 238.

${ }^{45}$ Zob. E. Przeszło, wyd. cyt., s. 342.

${ }^{46}$ Zob. poglądy E. Przeszło w przedmiocie istniejącego systemu kontrolowania zamówień publicznych - E. Przeszło, wyd. cyt., s. 1 i nast.

${ }^{47}$ Dz. U. z 2004 r., nr 19, poz. 177.

${ }^{48}$ Zob. E. Przeszło, wyd. cyt., s. 343.

${ }^{49}$ Tamże 
postępowanie, był najbliższy i najbardziej dostępny (najmniej skomplikowany) dla wszystkich zainteresowanych wykonawców ${ }^{50}$. Tego rodzaju braku nie jest w stanie zniwelować określona zawartością art. 181 ust. 1 u.p.z.p. instytucja powiadomienia zamawiającego o niezgodnej z prawem czynności podjętej przez niego lub o zaniechaniu czynności, do której jest on zobowiązany na podstawie ustawy. Podobieństwo do przedstawionej powyżej, a już niewystępującej instytucji opiera się na częściowo powtarzających się przesłankach zastosowania, jak również na tożsamości skutku. W przypadku uwzględnienia protestu (którego przedmiotem była czynności niezgodna $z$ prawem bądź też brak czynności po stronie zamawiającego - czynności nakazanej przez u.p.z.p.) zamawiający powtarzał oprotestowaną czynność lub dokonywał czynności bezprawnie zaniechanej. Podobna sytuacja ma miejsce pod rządami aktualnie obowiązującej u.p.z.p. w odniesieniu do powiadamiania zamawiającego. W razie uznania zasadności przekazanej informacji zamawiający powtarza czynność albo dokonuje czynności zaniechanej, informując o tym wykonawców w sposób przewidziany w ustawie. Co jednak ważne, dopuszczalność powiadamiania podmiotu zamawiającego ma ograniczony zakres merytoryczny. Tzw. uprawnienie informacyjne, będące pewnego rodzaju wytknięciem błędów zamawiającemu, jest dopuszczalne (w odróżnieniu do protestu) wyłącznie w zakresie czynności, na które w myśl art. 180 ust. 2 u.p.z.p. ${ }^{51}$ nie przysługuje zainteresowanemu odwołanie.

\section{Kontrolowanie zewnętrzne udzielania zamówień publicznych}

Kontrolowanie zewnętrzne pozornie uchodzi za najlepszą formę weryfikowania postępowań o udzielenie zamówienia publicznego. Punktem wyjścia dla niniejszego założenia jest gwarancja bezstronności i obiektywizmu wyrastająca z zewnętrznego usytuowania podmiotu kontrolującego względem kontrolowanego. To odrębna grupa podmiotów cechujących się samodzielnością i niezależnością w wykonywaniu swoich funkcji kontrolnych. Chodzi w tym wypadku o autonomiczność względem kompetencji Prezesa UZP - centralnego organu administracji rządowej w sprawach zamówień publicznych. Na tym etapie pojawia istotne pytanie, czy tego rodzaju niezależność z każdego dopuszczanego punktu widzenia zasługuje na pozytywną ocenę? Pozostaje bowiem w ścisłym związku z brakiem koordynacji i współpracy po stronie wszystkich wyposażonych w kompetencje kontrolne organów władzy publicznej. Wielość nie zawsze oznacza odpowiednią jakość, nie zawsze przynosi pożądane efekty w postaci usprawnienia weryfikowanych zachowań, postaw, struktur

${ }^{50}$ E. Przeszło, wyd. cyt., s. 343.

${ }^{51}$ Stosownie do brzmienia art. 180 ust. 2, jeżeli wartość zamówienia jest mniejsza niż kwoty określone w przepisach wydanych na podstawie art. 11 ust. 8, odwołanie przysługuje wyłącznie wobec czynności: wyboru trybu negocjacji bez ogłoszenia, zamówienia z wolnej ręki lub zapytania o cenę; określenia warunków udziału w postępowaniu; wykluczenia odwołującego z postępowania o udzielenie zamówienia; odrzucenia oferty odwołującego; opisu przedmiotu zamówienia, wyboru najkorzystniejszej oferty. 
czy też procedur. Co więcej, pewnego rodzaju niedomogów można doszukiwać się również nie tylko w ujęciu zbiorowym, ale i również w odniesieniu do każdego zewnętrznego kontrolującego z osobna. Nie chodzi w tym zakresie wyłącznie o błędy w uregulowaniach prawnych, czy też o błędne założenia co do statusu poszczególnych kontrolerów. W swej istocie działalność NIK oraz RIO zasługuje na pozytywną ocenę. Bliższa jednakże analiza działalności poszczególnych organów kontroli uwypukla również niedociągnięcia, uwidacznia brak efektywności i osłabia możliwość osiągania pożądanych rezultatów w procesie kontrolowania.

W myśl art. 1 Ustawy z dnia 23 grudnia 1994 r. o Najwyższej Izbie Kontroli $^{52}$ (dalej zw. u.o.n.i.k.) Najwyższa Izba Kontroli jest naczelnym organem kontroli państwowej stanowiącym - jak podnosi J. Lang - podwalinę całego systemu kontrolowania w państwie ${ }^{53}$. Działa na zasadach kolegialności. Kontroluje działalność organów administracji rządowej, Narodowego Banku Polskiego, państwowych osób prawnych i innych państwowych jednostek organizacyjnych. Może kontrolować działalność organów samorządu terytorialnego, samorządowych osób prawnych i innych samorządowych jednostek organizacyjnych, jak również inne podmioty oraz przedsiębiorców w zakresie, w którym wykorzystują one majątek lub środki państwowe lub komunalne oraz wywiązują się ze zobowiązań na rzecz Skarbu Państwa. NIK przeprowadza kontrolę pod względem legalności, gospodarności, celowości i rzetelności. W odniesieniu do podmiotów samorządowych kryteriami pozostającymi w dyspozycji są: legalność, gospodarność i rzetelność. Ogół przedstawionych powyżej uregulowań prawnych w sposób wyraźny uwidacznia, że NIK jako organ o wysokiej pozycji w strukturach władzy publicznej dysponuje szerokimi kompetencjami kontrolnymi. Dla potwierdzenia niniejszego można odwołać się do ustawowo określonej definicji kontrolowania przez kontrolerów NIK (art. 28 ust. 1 u.o.n.i.k.) ${ }^{54}$, która - co ważne - nie wykazuje odmienności od ogólnej interpretacji przedmiotowego procesu przyjętej przez doktrynę i orzecznictwo, a jednak została uznana za na tyle ważną, że otrzymała od ustawodawcy swoje ustawowe określenie. Sam fakt odrębnego definiowania kontroli NIK może świadczyć o szczególnej roli, o doniosłości omawianego organu w systemie organów kontroli bez względu na konkretny jej przedmiot. Jest najszersza z punktu widzenia podmiotowego, przedmiotowego, jak również przy uwzględnieniu stosowanych w działalności kryteriów kontrolnych ${ }^{55}$. Podlegają one jednakże różnicowaniu, a ściślej - stopniowemu ograniczaniu, począwszy od najszerszego ich zakresu przy działalności podmiotów państwowych, przez zawężenie do legalności, gospodarności i rzetelności w odniesieniu do dzia-

${ }^{52}$ Dz. U. z 2017 r., poz. 524 ze zm.

${ }^{53}$ Zob. M. Wierzbowski (red.), Prawo administracyjne, Warszawa 2008, s. 327 i nast.

${ }^{54} \mathrm{~W}$ myśl art. 28 ust. 1 postępowanie kontrolne ma na celu ustalenie stanu faktycznego w zakresie działalności jednostek poddanych kontroli, rzetelne jego udokumentowanie i dokonanie oceny kontrolowanej działalności.

${ }^{55}$ Zob. H. Nowicki, Sąowa kontrola częścia systemu prawnej kontroli zamówień publicznych, [w:] T. Kocowski, J. Sadowy (red.), wyd. cyt., s. 96. 
łalności samorządowej oraz w końcu do legalności i rzetelności w odniesieniu do podmiotów prywatnych (jednostek organizacyjnych i przedsiębiorców).

Działalność kontrolna NIK jest realizowana wszędzie tam, gdzie dochodzi do wydatkowania funduszami publicznymi ${ }^{56}$, a z punktu widzenia prowadzonych rozważań kontrolowaniu podlega sposób wydatkowania funduszy publicznych - realizacja udzielania zamówień publicznych. Pomimo statusu organu kontroli państwowej, zakres obszarów badawczych podlegających kompetencji NIK obejmuje również działalność podmiotów samorządowych i podmiotów prywatnych. Co istotne, to właśnie w odniesieniu do ich działalności ustawodawca w sposób wyraźny dokonuje podkreślenia, że zamówienia publiczne, a ściślej - ich wykonywanie, stanowi element kontrolowania NIK. Kolegialny charakter organu ma służyć zagwarantowaniu bezstronności i obiektywizmu, a wykonywanie czynności kontrolnych w siedzibie kontrolowanego ma wzmacniać efektywność czynności weryfikacyjnych. Co jednak ważne, szczególna pozycja organu w aparacie administracji państwa, jak również dopuszczalność współdziałania z innymi organami ${ }^{57}$, powołanymi przez państwo do kontrolowania, nie jest w stanie zagwarantować wysokich efektów pokontrolnych. Dużo bowiem nie zawsze oznacza efektywnie i dobrze. Może prowadzić do rozproszenia i rozmycia odpowiedzialności. A kwestia zamówień publicznych, a ściślej - sposób wydatkowania środków publicznych w związku ze zlecaniem realizacji dostawy, usługi czy też roboty budowlanej, stanowi jedynie wycinek ogółu kompetencji organu. Nie sprzyja również efektywności osiągania pożądanych wyników pokontrolnych brak uprawnienia do wydawania wiążących rozstrzygnięć. Zwieńczeniem bowiem procesu kontrolnego jest jedynie mające wiążącego charakteru wystąpienie pokontrolne, wskazujące wyłącznie na nieprawidłowości i sposób ich usunięcia (art. 53 i nast. u.o.n.i.k.). Nie jest w stanie temu przeciwdziałać zobowiązanie NIK w przedmiocie przekazywania informacji o wynikach kontroli stosownym organom władzy publicznej: Prezydentowi Rzeczpospolitej Polskiej, Prezesowi Rady Ministrów, wojewodom, organom jednostek samorządu terytorialnego (art. 8-9 u.o.n.i.k.), jak również kreowanie warunków do realizacji procesu społecznego kontrolowania na skutek podawania do wiadomości publicznej przez Prezesa NIK dokumentów będących zwieńczeniem procesu kontroli lub też pozostających w ścisłym związku z działalnością kontrolną organu.

Podobnie sytuacja wygląda, jeśli chodzi o działalność Regionalnych Izb Obrachunkowych, które w myśl art. 1 ust. 1 Ustawy z dnia 7 października 1992 r.

${ }^{56}$ Zob. P. Szustakiewicz, Kontrola..., s. 21.

${ }^{57} \mathrm{~W}$ myśl art. 12 organy kontroli, rewizji, inspekcji działające w administracji rządowej i samorządzie terytorialnym współpracują z NIK i są zobowiązane do udostępnienia NIK, na jej wniosek, wyników kontroli przeprowadzanych przez te organy, są zobowiązane do przeprowadzania określonych kontroli wspólnie i pod kierownictwem NIK, są zobowiązane do przeprowadzania kontroli doraźnych na zlecenie NIK. NIK może przeprowadzić również kontrolę wspólnie z naczelnymi organami kontroli Wspólnot Europejskich oraz naczelnymi organami kontroli innych państw. 
o regionalnych izbach obrachunkowych ${ }^{58}$ są państwowymi organami nadzoru i kontroli gospodarki finansowej. Dzieje się tak, mimo iż brzmienie przywołanej regulacji w sposób szeroki i ogólny wyznacza zakres kompetencji organu, dając wyraz silnego oddziaływania na postępowanie podmiotu kontrolowanego. Określony jako organ nadzoru nad gospodarką finansową dokonuje jedynie kontrolowania gospodarki finansowej oraz zamówień publicznych (czy też w tym zamówień publicznych). Przez zawartość ust. $2 \mathrm{w}$ art. 1 u.r.i.o. ustawodawca daje wyraz szczególnego znaczenia weryfikacji procedury związanej z udzielaniem zamówienia publicznego. Mimo iż zamówienia publiczne w rozumieniu prowadzonych postępowań zawierają się (z racji wydatkowania środków publicznych) w ogólnie określanym pojęciu gospodarki finansowej, ustawodawca w sposób wyraźny i odrębny determinuje legitymację do kontrolowania zamówień publicznych (procedur związanych z dysponowaniem funduszami publicznymi). Kontrolowanie to ma ograniczony zakres podmiotowy, albowiem obejmuje gospodarkę finansową i zamówienia publiczne: jednostek samorządu terytorialnego, związków metropolitalnych, związków międzygminnych, stowarzyszeń gmin oraz stowarzyszeń gmin i powiatów, związków powiatów, związków powiatowo-gminnych, stowarzyszeń powiatów, samorządowych jednostek organizacyjnych, w tym samorządowych osób prawnych, innych podmiotów w zakresie wykorzystywania przez nie dotacji przyznawanych z budżetów jednostek samorządu terytorialnego. Ograniczenie podmiotowe nie jest jedynym, które w sposób negatywny może oddziaływać na efektowność i skuteczność kontrolowania RIO. Kontrolowanie kompleksowe uchodzące za najlepszą formę sprawdzania i weryfikacji gospodarki finansowej jednostek samorządu terytorialnego, o którym stanowi ustawodawca na gruncie art. 7 u.o.r.i.o., jest przeprowadzane rzadko - raz na cztery lata, a co więcej - po uprzednim powiadomieniu o terminie kontroli nie później niż na 7 dni przed planowanym podjęciem badania sprawdzającego. Mierniki zaś stosowane w prowadzonych czynnościach sprawdzających podlegają różnicowaniu w zależności od rodzaju zadań realizowanych przez ,podmioty samorządowe”. W zakresie realizacji zadań własnych punktem odniesienia w procesie kontrolowania jest kryterium legalności i zgodności dokumentacji ze stanem faktycznym. Z kolei w obrębie zadań administracji rządowej kontrolowanie odbywa się przy użyciu kryterium celowości, rzetelności i gospodarności. Zwieńczeniem procedury kontrolnej jest wystąpienie pokontrolne, co jednak ważne - w swej istocie niemające możliwości władczego oddziaływania, wymuszenia na kontrolowanym stosownej poprawy. Dzieje się tak, mimo iż sam ustawodawca przyznaje Prezesowi Izby uprawnienie do zarządzenia sprawdzenia wykonania wniosków pokontrolnych przez kontrolowanego. Dla potwierdzenia niniejszego można przywołać brzmienie art. 9 ust. 3 u.r.i.o., na gruncie to którego ustawodawca sam dopuszcza możliwość niewykonania wniosków pokontrolnych przez podmiot kontrolowany. Wskazuje bowiem, że w sytuacji ich niewykonania jednostka kontrolowana jest zobowiązana jedynie do

\footnotetext{
${ }^{58}$ Dz. U. z 2016 r., poz. 561.
} 
zawiadomienia Izby w terminie 30 dni od dnia doręczenia wystąpienia o przyczynach ich niewykonania. Wystąpienie pokontrolne wskazuje na źródła i przyczyny nieprawidłowości, ich rozmiary, osoby odpowiedzialne oraz wnioski zmierzające do ich usunięcia i usprawnienia badanej działalności. Sugerowane propozycje zmian doręcza się kontrolowanej jednostce nie później niż w terminie 60 dni od dnia podpisania protokołu kontroli. Pewnego rodzaju „lekarstwem na bolączki” związane z niewiążącym charakterem wskazówek pokontrolnych może być raport o stanie gospodarki finansowej jednostki samorządu terytorialnego sporządzany przez Izbę na podstawie wyników prowadzonej działalności kontrolnej (art. 10 a u.r.i.o.). Odwołuje się on w swej treści do powtarzających się nieprawidłowości, jak również do zagrożeń związanych z niewykonywaniem zadań ustawowo nałożonych na jednostkę. Raport jest przekazywany organom stanowiącym i wykonawczym jednostek samorządu terytorialnego. Posłużenie się określeniem wskazującym jedynie na fakt możności przeciwważenia niedociągnięć związanych z brakiem możliwości władczego oddziaływania $\mathrm{w}$ aspekcie udzielania zamówień publicznych nie ma w tym wypadku przypadkowego charakteru. Ustawodawca przewiduje, że raport może nie musi być wcale sporządzany, jest bowiem przygotowywany „w razie potrzeby”, a o konieczności jego sporządzenia rozstrzyga Kolegium Izby w drodze uchwały. A zatem ani sam fakt dopuszczalności jego opracowania, ani zawartość treściowa nie stanowi żadnej gwarancji umocnienia działalności kontrolnej RIO w obszarze udzielania zamówień publicznych.

\section{Zakończenie}

Przedstawione powyżej rozważania w sposób wyraźny i jednoznaczny wskazują, że aktualny stan systemu organów kontroli zamówień publicznych wymaga zrewidowania i wprowadzenia stosownych zmian. Cechuje się wysokim poziomem rozproszenia przy jednoczesnej dominującej roli organów kontrolnych i ich uprawnień ściśle sprawdzających, a nie kompetencji nadzorczych. Jego zdecentralizowanie ${ }^{59}$ pociągnęło za sobą osłabienie pozycji Prezesa UZP, który ustawowo określany jako centralny organ administracji rządowej w sprawach zamówień publicznych powinien zajmować (a nie zajmuje) naczelne miejsce w systemie organów ich kontrolowania. Nieprzypadkowo w doktrynie jest określany mianem „gospodarza systemu" ${ }^{60}$, ale jak wynika z obowiązujących uregulowań: jedynie o ograniczonych kompetencjach działania weryfikacyjnego. Co istotne, nie chodzi w tym wypadku o sam fakt pozbawienia go w zdecydowanej mierze kompetencji nadzorczych, ale o zrównanie jego kompetencji z kompetencjami innych organów, w obrębie to których działalności kontrola postępowań o udzielenie zamówienia publicznego stanowi jedynie fragment większej całości, jest jedynie wycinkiem procedur weryfikacyjnych pozostają-

\footnotetext{
${ }^{59}$ Takim pojęciem posłużyła się E. Przeszło - zob. E. Przeszło, wyd. cyt., s. 231.

${ }^{60}$ Zob. P. Szustakiewicz, Kontrola..., s. 35.
} 
cych w ich dyspozycji. Prezes UZP nie został wyposażony w uprawnienia koordynacyjne, nie dysponuje również żadnymi uprawnieniami, które legitymowałyby go do wpływania na czynności kontrolne innych podmiotów lub też umożliwiałyby mu harmonizację osiąganych rezultatów pokontrolnych. Dopuszczalności współpracy czy też zlecania czynności kontrolnych można raczej dopatrywać się w działalności NIK, ale nie jest to organ ograniczający się w swym działaniu wyłącznie do weryfikowania działalności związanej z udzielaniem zamówień publicznych. Rynek zamówień publicznych wymaga występowania jednego organu nadzorczego, działającego kompleksowo, o ściśle określonych kompetencjach władczego oddziaływania. Chodzi w tym wypadku o organ usytuowany na zewnątrz - tj. poza uczestnikami postępowań o udzielenie zamówienia publicznego i w całkowitym od nich oderwaniu, o właściwościach silnie skoncentrowanych na rynku zamówień publicznych i na zagwarantowaniu prawidłowości dysponowania środkami publicznymi ${ }^{61}$. Jego ustanowienie będzie stanowiło pierwszy krok do sprawnie funkcjonującego systemu zamówień publicznych, który - jak wskazuje P. Szustakiewicz - ma sprzyjać i sprzyja rozwojowi zarówno naczelnych instytucji państwa, jak i jego gospodarki ${ }^{62}$.

\section{Literatura}

Babiarz S., Prawo zamówień publicznych. Komentarz, wyd. III, System Informacji Prawnej Lex/el.

Boć J. (red.), Prawo administracyjne, Wrocław 2010.

Dawidowicz W., Zagadnienia ustroju administracji państwowej w Polsce, Warszawa 1970.

Duszniak S., Terminologia z zakresu czynności nadzorczych i kontrolnych, Gazeta Administracyjna, 1948, nr 1-2.

Dzierżanowski W., Jerzykowski J., Stachowiak M., Prawo zamówień publicznych. Komentarz, wyd. VII, System Informacji Prawnej Lex/el.

Garbala E., Kontrola zamówień publicznych prowadzona przez Prezesa Urzędu Zamówień Publicznych, FK, 2008, nr 1-2.

Gola J., Kontrola Prezesa Urzędu Zamówień Publicznych jako instrument zapobiegania korupcji w administracji publicznej, [w:] T. Kocowski, J. Sadowy (red.), Kontrola zamówień publicznych, Wrocław-Warszawa 2013.

Horubski K., Publiczno- i prywatnoprawne elementy zamówień publicznych, Państwo i Prawo, 2009, $\mathrm{nr} 7$.

Jagielski J., Kontrola administracji publicznej, Warszawa 2005.

Jędrzejewski S., W kwestii ustawowej definicji pojęcia „nadzór”, Organizacja-Metody-Technika, 1989, nr 8-9.

Kociński C. (red.), Nadzór administracyjny. Od prewencji do weryfikacji, Wrocław 2006.

Kocowski T., Sadowy J. (red.), Kontrola zamówień publicznych, Wrocław-Warszawa 2013.

Kurowska A., Postępowanie odwoławcze przed KIO jako środek korygujący w postępowaniu o udzielenie zamówienia publicznego, [w:] T. Kocowski, J. Sadowy (red.), Kontrola zamówień publicznych, Wrocław-Warszawa 2013.

${ }^{61}$ Zob. stanowisko M. Szydło w przedmiocie organu nadzorującego: M. Szydło, Prawna koncepcja zamówienia publicznego, Warszawa 2014, s. 112 i nast.

${ }^{62}$ Zob. P. Szustakiewicz, Kontrola..., s. 13. 
Marak K., Kontrola udzielania zamówień publicznych $w$ świetle instytucji kontroli i nadzoru w materialnym prawie administracyjnym, [w:] T. Kocowski, J. Sadowy (red.), Kontrola zamówień publicznych, Wrocław-Warszawa 2013.

Mituś A., Kontrola zarzadcza a udzielanie zamówień publicznych-zarys problematyki, [w:] T. Kocowski, J. Sadowy (red.), Kontrola zamówień publicznych, Wrocław-Warszawa.

Norek A.E., Prawo zamówień publicznych. Komentarz, wyd. III, System Informacji Prawnej Lex/el.

Norek A.E., Prawo zamówień publicznych. Komentarz, Warszawa 2005.

Nowicki H., Sądowa kontrola częścia systemu prawnej kontroli zamówień publicznych, [w:] T. Kocowski, J. Sadowy (red.), Kontrola zamówień publicznych, Wrocław-Warszawa 2013.

Ochendowski E., Prawo administracyjne, Torun 2006.

Panasiuk A., Czy kontrola może szkodzić?, [w:] T. Kocowski, Sadowy J. (red.), Kontrola zamówień publicznych, Wrocław-Warszawa 2013.

Pieróg J., Prawo zamówień publicznych. Komentarz, System Informacji Prawnej Legalis/el.

Przeszło E., Kontrola udzielania zamówień publicznych, Poznań 2013.

Puchacz K., Kontrola zamówień publicznych, Wrocław 2010.

Skubiszak-Kalinowska I., Wiktorowska E., Prawo zamówień publicznych. Komentarz, System Informacji Prawnej Lex/el.

Stachowiak M., Jerzykowski J., Dzierżanowski W., Kwieciński T., Łysakowski W., Prawo zamówień publicznych. Komentarz, wyd. 2, Warszawa 2006.

Sylwestrzak A., Kontrola administracji publicznej w III Rzeczpospolitej Polskiej, Gdańsk 2006.

Szustakiewicz P., Czy istnieje system kontroli zamówień publicznych, [w:] T. Szustakiewicz P., Kontrola zamówień publicznych. Zagadnienia praktyczne, Warszawa 2011.

Szydło M., Prawna koncepcja zamówienia publicznego, Warszawa 2014.

Wierzbowski M. (red.), Prawo administracyjne, Warszawa 2008.

Wiśka-Rużewicz K., Rola wykonawcy jako podmiotu kontrolującego prawidłowość udzielenia zamówienia, [w:] T. Kocowski, J. Sadowy (red.), Kontrola zamówień publicznych, Wrocław-Warszawa 2013.

Zimmermann J., Prawo administracyjne, Warszawa 2008.

\section{Źródla prawa}

Ustawa z dnia 14 czerwca 1960 r. Kodeks postępowania administracyjnego (Dz. U. z 2017, poz. 1257 ze zm.).

Ustawa z dnia 17 listopada 1964 r. Kodeks postępowania cywilnego (Dz. U. z 2018 r., poz. 1360 ze $\mathrm{zm}$.).

Ustawa z dnia 7 października 1992 r. o regionalnych izbach obrachunkowych (Dz. U. z 2016 r., poz. 561).

Ustawa z dnia 23 grudnia 1994 r. o Najwyższej Izbie Kontroli (Dz. U. z 2017 r., poz. 524 ze zm.).

Ustawa z dnia 6 września 2001 r. o dostępie do informacji publicznej (Dz. U. z 2018 r., poz. 1330 ze $\mathrm{zm}$.).

Ustawa z dnia 29 stycznia 2004 r. Prawo zamówień publicznych (Dz. U. z 2017, poz. 1579 ze zm.).

Ustawa z dnia 29 stycznia 2004 r. Prawo zamówień publicznych (Dz. U. z 2004 r., nr 19, poz. 177).

Ustawa z dnia 28 lipca 2005 r. o kosztach sądowych w sprawach cywilnych (Dz. U. z 2018 r., poz. 300).

Rozporządzenie Prezesa Rady Ministrów z dnia 15 marca 2010 r. w sprawie wysokości i sposobu pobierania wpisu od odwołania oraz rodzajów kosztów w postępowaniu odwoławczym i sposobu ich rozliczania (Dz. U. z 2010 r., nr 41, poz. 238).

Rozporządzenie Prezesa Rady Ministrów z dnia 15 marca 2010 r. w sprawie wysokości i sposobu pobierania wpisu od odwołania oraz rodzajów kosztów w postępowaniu odwoławczym i sposobu ich rozliczania (Dz. U. z 2018 r., poz. 972). 
Rozporządzenie Prezesa Rady Ministrów z dnia 22 marca 2010 r. w sprawie regulaminu postępowania przy rozpoznawaniu odwołań (Dz. U. z 2018 r., poz. 1092).

Wyrok WSA w Warszawie z dnia 28 lutego 2008 r., V SA/Wa 2614/07.

Postanowienie WSA w Warszawie z dnia 29 grudnia 2005 r., III SA/ Wa 3202/05.

Wyrok KIO z dnia 7 marca 2012 r., sygn. akt. KIO 384/12.

Wyrok KIO z dnia 3 lipca 2012 r., sygn. akt. KIO 1275/12.

Wyrok KIO z dnia 20 lutego 2015 r., sygn. akt. 242/15.

Wyrok KIO z dnia 20 lutego 2015 r., sygn. akt. 1479/14. 